MYRA MARX FERREE University of Wisconsin

\title{
Filling the Glass: Gender Perspectives on Families
}

The challenge feminist scholarship posed to family studies has been largely met through the incorporation of research on gender dynamics within families and intersectional differences among them. Despite growing attention to gender as performance and power in more diverse families, the more difficult work of understanding the dynamics of change among institutions including the family and using intersectional analyses to unpack relationships of power is only beginning. Reviewing the contributions researchers have made in these areas over the last decade and applying the idea of circuits to the study of care work, this article points to promising practices for both improving research on gender and families and contributing to the slow drip of institutional change.

Two decades ago, I argued against a purely social psychological understanding of gender as a socialized role carried by individuals and primarily produced in and by families (Ferree, 1990). Instead, I suggested that thinking of gender in a more multilevel and dynamic way would also demand thinking of families differently. Drawing on feminist research, I challenged the functionalist assumptions that families were separate spheres of interaction with internally unitary interests, a natural and universal specialization of roles, and a foundational position in the social order. Invited

Department of Sociology, University of Wisconsin, Room 7103, Sewell Social Science Building, 1180 Observatory Dr., Madison, WI 53706-1393 (mferree@ssc.wisc.edu).

Key Words: caregiving, discourse, feminist theory, gender, intersectionality, power. to assess how gender research informs family studies now, I focus on both what has changed and what remains marginalized in relation to this agenda. In this article, I suggest that the half-full, half-empty glass metaphor aptly describes how the field has responded in the past decade to the challenges of analyzing gender as a significant social relationship.

The fullness of the glass is apparent in the volume of empirical research on families that takes gender relations rather than sex roles as its core analytic concept for thinking about women and men (see overviews in Coltrane \& Adams, 2008; Lloyd, Few, \& Allen, 2009). Especially at the microlevel, the dynamics of gender as power (Bittman, England, Sayer, Folbre, \& Matheson, 2003) and as performance (Fox \& Murry, 2000; Jurik \& Siemsen, 2009) have emerged as topics of general concern. The emptiness is revealed by the continuing force of functionalism in defining a normative standard family, still considering family structure difference in terms of deviance (Walker, 2009) and gender as a role in a single institution rather than an inequality that cuts across multiple institutions (Risman, 2004). The massive increase in attention to family diversity has only begun to be connected to the dynamics of change within and across multiple institutions and to the relations of gender with other inequalities, as McDowell and Fang (2007) pointed out. Wills and Risman (2006) emphasized the progress made but also pointed out the continuing challenge to go beyond a token recognition of gender. I suggest that the field of family studies has not been able to fully incorporate gender analyses because it has still rarely placed families explicitly in a dynamic field of economic and political changes in which the struggles over gender relations, 
as well as over other forms of inequality, are recognized as collective as well as individual. Lacking such an analysis, family change has continued to be seen more as a crisis than an opportunity for challenging pervasive structures of societal inequalities.

Rather than presenting a representative sample of gender research in family studies, this review focuses on the studies that have engaged family, gender, and social change in theoretical and empirical interaction, using this work to show the value family scholars gain by taking such a multilevel and dynamic view of gender. It begins with a brief overview of the places where gender has been best incorporated within family studies and then looks at research that moves past a micro-macro division to ask intersectional, multilevel questions about gender dynamics. This perspective, still often found only at the margins of family studies, approaches families as an institutional site in which gender-based relations of inequality are often contested, sometimes changed, and always connected to other gendered institutions and inequalities (Cooke, 2006; Haney \& Pollard, 2004; McDowell \& Fang, 2007).

The two dynamic threads that I follow are the contested multi-institutional relationships among families, states, and markets that are gendered in locally specific, temporally dynamic, and systemically meaningful patterns and gender as a structural inequality related to other inequalities such as race, class, age, and sexuality. I also use feminist research on care to demonstrate some contributions of a simultaneous institutional and intersectional analysis of gender and families. I point to issues of contradiction and resistance that this research has posed for understanding changes in gender relations, not just as happening to or in families, but as wide-ranging societal transformations in which the institution of family matters. I conclude by suggesting that attention to power and change will inevitably make studies of gender and family political.

\section{ASSESSING THE PARAMETERS OF GENDER AND FAMILY RESEARCH}

To see what a gender perspective brings to family studies, it is first necessary to recognize the vast transformation of the field created by feminist critique. These changes began with the arguments by Jessie Bernard that there are gendered experiences of the institution ("'his" and "her" marriage), continued with the challenges to the dominance of role theory in the 1980 s, and produced political fights over gendered changes in family relations in the 1990s (see earlier decade reviews by Ferree, 1990, and Fox \& Murry, 2000). Feminist research on families still engages the questions generated by these struggles, building an impressively large body of research (reviewed by Lloyd et al., 2009) that has now made the relevance of gender hard to ignore, even for those who feel the feminist challenge to patriarchal marriage has gone too far (Waite \& Gallagher, 2003; Wilcox, 2004).

Indeed, the glass is so full of studies considering gender as a variable that reviewing all this work would be impossible (consider the gender comparisons offered in many of the articles in this issue, particularly on lesbian, gay, bisexual, and transsexual [LGBT] families; work-family relations; family policy; and power, conflict, and violence). This review regretfully omits many such studies and also points to the comprehensive set of reviews in Lloyd et al. (2009) as well as fine discussions of gender and family issues in Calasanti and Slevin (2006) and Coltrane and Adams (2008) to cover some of the other gaps.

A broad sense of what has been accomplished by bringing gender into family studies can be conveyed by considering how well incorporated some topics have become despite how radical they seemed when first introduced. Most conspicuously, assessing the causes and consequences of the division of household labor in married couples has become routine, with much of this research proceeding from the assumption that gender itself, not merely a rational allocation of time, is fundamental (for excellent recent contributions, see Gupta, 2006, and Treas \& deRuijter, 2008). There has been much attention to the irrationalities in these arrangements, particularly focusing on assessing the claim that wives who earn more than their husbands engage in a compensatory display of gender conformity by doing more domestic labor (Bittman et al., 2003; Cooke, 2006; Gupta, 2007). Microlevel social constructionism as an approach to gender relations has lost its novelty, but as Deutsch (2007) argued, much of this work has been more about "doing', than "undoing'" gender. Overall, it is no longer extraordinary to consider the household as a place in which gender is produced and performed through the provision 
of housework and childcare - $\mathrm{a}$ " gender factory" as Berk (1985) memorably called it.

A second major accomplishment lies in the now common acknowledgment that the work-family balance issues faced primarily by women reflect large, historically and politically meaningful shifts in gender arrangements (Moen \& Roehling, 2004; Stone, 2007; Williams, 2000). Structural research has provided tools for understanding the complexity of this transformation, showing how family interactions reflect wider but nationally and historically specific shifts in the material conditions of production and reproduction (Coontz, 2005; Peterson, 2005; Thistle, 2006) and related expectations about self and society (Cherlin, 2009; Rosenfeld, 2007). Even those who are skeptical about the merits of the dual career family and gender equality as societal norms have recognized that they are part of an ongoing restructuring of the economy (e.g., Wilcox, 2004). Looking at gender equality effects of the social organization of childcare has also become well accepted (Cancian, Kurz, London, Reviere, \& Tuominen, 2002).

Third, the lens of family studies has widened to include more studies of gender relations as shaping diverse family types, including lesbian and gay families (Goldberg, 2009; Oswald, 2002; Stacey, 2005), transnational families (Mahalingham, Balan, \& Molina, 2009; Parrenas, 2001), and families of color in the United States (Few, 2007; Hill, 2005). Research on poor and nonpoor single mothers has proliferated as well, analyzing both the challenges of material survival and the impact of cultural expectations on their struggles to "do family" in the face of continued normative disapproval (Hays, 2002; Hertz, 2006; M. Nelson, 2003). These studies provide an essential knowledge base for seeing gender relations within the family as interconnected with other forms of social inequality that are also materially changing and culturally contested.

Nonetheless there is also good reason to present the glass as half empty and to argue that a gender perspective is still profoundly marginalized. Critical reviews of family policy studies have shown how, even in gender-political controversial domains such as gay parenting (Stacey \& Biblarz, 2001) or extramarital childbirth (O'Connor, 2001), most research designs have accepted the gender norms of the status quo as unfailingly appropriate. Although the discourse of family change has been deeply politicized for at least two decades, and perhaps much longer (M. Adams, 2007; Coltrane, 2001; Smock, 2004), the dominant framing of the debate has been that the status quo represents science and only feminist claims are political (Presser, 1997). Pitting "family" against "feminism," conservative American activists have vigorously mobilized both at home and abroad to argue for the continued institutionalization of different family responsibilities for men and women (Buss \& Herman, 2003). The connection between gender arrangements and family change, a theme throughout the social science of the 20th century (Smock), has been often framed in family studies as a threat to the (functional) family, understood ahistorically, as Coltrane noted. In response, much American social policy has adopted the cause of "healthy relationships" defined as those organized around gender difference (Heath, 2009).

Walker (2009) recently deplored how little feminist research entered mainstream family journals and how difficult she found it, as the editor of this journal, to bring in a critical, socially dynamic gender analysis, when many of the research studies she reviewed still spoke primarily to what she called a "deeply conservative" functionalist agenda: one in which married, heterosexual, White, middle-class families with young children and a harmony of interests appeared as the norm (p. 19). She applauded the contributions of particular researchers, but her overall conclusion was one of missed opportunities for the field of family studies. Additionally, the ongoing conceptualization of gender in terms of roles situated within the family as a single institution has served to depoliticize the understanding of processes that connect inequalities across multiple institutional sites. Allen (2001) and Coltrane and Adams (2003) noted how this process contributes to framing research on gendered family change in individualized, social problem terms.

The chief difference between emphasizing the full or empty state of the glass may be found in whether gender analysis is defined more or less loosely. A loose definition of gender as a variable distinguishing women and men as individuals or as defining relationships located within the context of family is omnipresent. Studies fitting this definition often have employed the theoretically disconcerting language of 
"'gender role," which either encapsulates gender within a single institution or turns role into a synonym for cultural stereotype. Far fewer studies have applied the feminist-inspired and theoretically rigorous definition of gender as a relationship of power connected to institutional processes organizing - and changing - families. Even though stressing the half-full glass, the broad review of family journals by Wills and Risman (2006) found an important gulf between family studies that considered gender at all, which made up $26 \%$ of the articles between 1992 and 2002, and those that explicitly brought in a feminist perspective (about 6\%).

Overall, it is important to acknowledge that families have become increasingly seen as sites where gender matters, but also to recognize the limited ways that gender has been seen to matter. Gender too often has remained personalized at the level of individual struggles and depoliticized by reducing social inequalities to differences. Feminist questions about conflicts of interest within the family and the connections between families and changes in culture, economics, and politics have entered the field of family studies, but the answers have often stressed adaptation rather than transformation, as some reviewers have already noted. For example, Stacey and Biblarz (2001) asked whether the defensive claim that children raised by gay and lesbian parents are "not different" from the heterosexual norm needs to be challenged by considering when and how sexual norms deserve to be transformed in ways that these parents may be able to do more effectively. Danby (2007) similarly asked whether the feminist focus on gender relations in couples (whether married or not, gay or straight) provided an effective way of challenging normative boundaries on the family, even for heterosexuals. Bringing gender into family studies but trying to make it uncontroversial and apolitical by disconnecting it from the ongoing struggles over what kinds of gender relations are socially valued and supported is a pyrrhic victory.

Over the past decade, some researchers have challenged the domestication of gender studies with a more dynamic, multilevel, and critical understanding of gender. McDowell and Fang (2007) critically reviewed the strengths and weaknesses of multicultural family scholarship, saying that gender scholars are beginning to assume that dynamics within families, and those between families and broader social systems, are reciprocally influential. Relationships between family members are deeply influenced by social discourses and material realities associated with the social locations of each member and the family as a whole. Likewise, power dynamics within families, and the role families play in the transmission of cultural and social knowledge, continually influence broader social structures. (p. 555)

In the rest of this review, I examine the gender research of the past decade that has avoided the implicitly functionalist separate spheres model of family structures, social interactions, and individual beliefs and behavior by bringing the wider political and cultural context of these processes into its study design. This research has not only studied what the gender relations of the present are like but has also attempted to explain the interests and injustices connected to these arrangements, how and by whom they are being resisted, and why, in the interest of gender as well as family justice, they can and should be changed.

\section{ANALYZING GENDER: THEORETICAL ADVANCES AND CHALLENGES}

The challenge for gender analysis in this decade has been to integrate the structural story of transformation at the macrolevel with a consideration of women's and men's individual and collective agency in families and family politics. Like social constructionist views of families (e.g., Holstein \& Gubrium, 1999), the gender perspective has emphasized the agency of persons and organizations, the meanings that social action carries, and the microprocesses of interaction (Jurik \& Siemsen, 2009). But unlike social constructionism, gender analysis situates these meanings and microprocesses in the context of multiple, intersecting historical forceseconomic, demographic, and political - that are both material and discursive (Deutsch, 2007; K. A. Martin, 2009; Risman, 2004). Like structural analyses of culture (Cherlin, 2009), policy (Harrington Meyer \& Herd, 2007), or the economy (Thistle, 2006), these analyses have made conflict and change over time visible and explicitly considered political interests (Gornick \& Meyers, 2009). But unlike studies that remain solely macrolevel, research driven by gender theory also has tried to bring individual and collective agency into the story of social change. By 
highlighting the cultural and material resources that people and groups bring to their struggles, such research has sought to identify practices with potential for changing structures of inequality (Jacobs \& Gerson, 2004; Macdonald, 2010; Williams, 2000; Williams \& Boushey, 2010).

This sort of gender analysis of the family as an interactive institution integrated with politics, the economy, and civil society and entwined in relations of inequality based on race, sexuality, ethnicity, disability, and age remains outside the mainstream, as feminist reviewers have often pointed out (e.g., Calasanti \& Slevin, 2006; Few, 2007; McDowell \& Fang, 2007). Its integration of macro-, meso-, and microconcerns represents both a contribution that gender theoretical research has distinctively added to the understanding of families in the past decade and a promising direction for moving the field forward.

\section{Theoretical Advances}

A gender perspective has also been called gender relations theory, gender as a social structure, gender as an institution, and an intersectional gender analysis (Lorber, 2005; P. Y. Martin, 2003a; Risman, 2004). At its core, the gender perspective rejects gender as a static norm or ideal (the so-called gender role), and instead defines gender as a social relation characterized by power inequalities that hierarchically produce, organize, and evaluate masculinities and femininities through the contested but controlling practices of individuals, organizations, and societies. The differences between and among women and men are thus not only seen as socially constructed but also as politically meaningful. Individual gendering activities are situated in larger structures that have their own institutionalized gender practices and meanings (P. Y. Martin, 2003a). The macro-micro dynamic is integral to this theoretical perspective (Anderson, 2005).

Over the past decade, research addressing gender as a multilevel structural relationship (Risman, 2004) has added to, rather than replaced, the microsocial view of gender as an interpersonally evaluated performance, or “doing gender" (West \& Zimmerman, 1987), an approach that has continued to grow in theoretical sophistication in its own right. The social constructionist view of gender has itself expanded to encompass more concern with interactional analyses of multiple inequalities ("doing difference"; Fenstermaker \& West, 2002), the material and discursive resources available for struggles to "undo" gender (Blume \& Blume, 2003; Deutsch, 2007; Risman, 2009), and the contradictions between what is "said and done" and varying degrees of awareness in the "saying and doing" (P. Y. Martin, 2003b). Macrostructures have been identified not solely in material inequalities of power and resources but also in the cultural schemas and the discourses of difference, power, and belonging that define social groups such as communities, nations, races, and genders (Gal \& Kligman, 2000; Hancock, 2004).

Such macrolevel culture can be seen in specific gendered discourses of identity and value. Gender analysis attempts to untangle how women use such cultural narratives. For example, K. A. Martin (2009) looked at variation in how mothers conveyed norms of heterosexuality to their children, and Pyke and Johnson (2003) identified the tensions in self-conceptions of daughters of Korean and Vietnamese immigrants in relation to a narrative of absolute opposition between patriarchal Asian and egalitarian White American cultures. Such culturally grounded identities are then seen as crucial in negotiating gender, for example, in conflicts between mothers and nannies over good mothering (Macdonald, 2009) and between parents and children over gendered behaviors (Kane, 2006). The reverse is also true: Such struggles at the interactional level are understood as part of the slow process of transforming cultural norms, what Sullivan (2004) called the "slow drip" version of a gender revolution.

As it has grown and developed, gender theory has approached families not as a separate sphere at all, but as only one of a number of interlinked institutions where gender relations are constructed, reproduced, and transformed (Albiston, 2007; Coontz, 2005; Moen \& Roehling, 2004; Presser, 2004). This gender perspective understands politics in terms of ongoing multilevel struggles over the nature of intersectional power relations, not merely those occurring in formal institutional contexts in and around governments and social movements (Brush, 2003; Pascale, 2007). For example, the politics of care does not only encompass the important macrolevel questions of when and how states and markets should be used to complement and support family-based care (Daly \& Rake, 2003; Gornick \& Meyers, 
2009). It also refers to the mesolevel organizational conditions under which care is provided in specific cases, how these draw on and create social inequalities, and when and how such institutions are changed (Hobson \& Fahlen, 2009; Presser, 2004). It includes microlevel questions of individual identities and interpersonal relationships among care workers, employers, and recipients of care as sites of struggle (Macdonald, 2010; Tuominen, 2003). Each of these levels is seen as relating systematically to each other, with gender a meaningful structural relation needing analysis at and between each level (Risman, 2004). Gender as an inequality operates in, on, with, and through family as an institution on all these levels.

By defining power as a multilevel and dynamic relation that enables, constrains, and gives meaning to action, recent gender analyses of families have focused much needed attention on both institutions and intersectionality (Haney \& Pollard, 2004). Institutions consist of the social formations through which persons and groups are organized in meaningful relations over time (P. Y. Martin, 2003a). Families are social institutions existing in a multi-institutional field in which social processes (such as production, reproduction, and representation) are organized through gender inequality, although never by this relationship alone (Walby, 2009). Intersectionality refers to the active interaction of the various relations of inequality such as race, class, sexuality, gender, and age within and across all of the institutions of society (Anderson, 2005). All families must manage individual intersectionality, because each member has been socially assigned multiple identities (e.g., gender, race, age, and nationality). Families as institutions are also located in intersections of structural relations of inequality within and across all other institutions (economic, governmental, religious, and civic) at all levels from local to transnational (McCall, 2005).

In the following sections, I separately review contributions to the understanding of institutional and intersectional analysis of families offered from a gender perspective. Afterward, I illustrate the potential for integration of institutional and intersectional issues by comparing American and European feminist approaches to understanding of care as a gendered system that links families and individuals within and across diverse institutional inequalities at multiple levels of analysis and opens differing spaces for social change.

\section{INSTITUTIONAL ANALYSIS: SITES AND Circuits of Gender POWER}

A dynamic gender analysis treats institutions such as families, states, and markets as interconnected sites rather than separate spheres or even discrete systems (Howell, 2007). At the sites of family relations - both in and across individual households - gender power gets exercised and institutionalized. Gender and family relations also depend on what Howell (p. 424) called the circuits connecting families with many other institutions, such as government and formal employment, in particular settings. Walby (2009) portrayed these circuits as feedback loops, both positive (stabilizing) and negative (destabilizing) for the relations of inequity. She further argued that older notions of systems theory were wrong, not because they focused on feedback, but because they assumed equilibrium and treated sites as if they were closed systems. Viewing gender only in relation to family, class in relation to the economy, and race in relation to states and nations distorted analyses of these inequalities and institutions by hiding the dynamics of change. For example, the legal definition of marriage and allocation of benefits on that basis has become an obviously contested and changing institutional circuit between family and state, simultaneously organized by gender, sexuality, age, and nationality. To grasp the implications of this struggle for families demands studying processes across levels of analysis and institutional domains.

\section{From Structures Down and From Agents Up}

The institutional aspect of gender relations theory places families in a social context larger than themselves. Moving beyond separate spheres ideology, it deals explicitly with the issues of stability and change, the unevenness and contradictions of gender relations within and across social locations, and the balance between structure and agency in those sites. Albiston (2007), Blair-Loy (2003), Hobson and Fahlen (2009), Jacobs and Gerson (2004), Moen and Roehling (2004), and Presser (2004) have offered varying conceptualizations of the circuits of work and family that follow this model. 
In turn, the activity emphasized by a dynamic institutional approach moved analysts away from seeing either women or men as "actors whose interests could be read directly from their economic position by invoking utilitarian assumptions," toward a conception of them as "boundedly-rational, operating with repertoires - of collective action, of organization, of identity - that are culturally constituted in ways specific to time and place' (J. Adams, Clemens, \& Orloff, 2005, pp. 36-37). The power of inequality is not only economic or demographic, but also expressed in cultural knowledge and self-understandings (P. Y. Martin 2003b). These discourses and schemas provide tools for making personally meaningful choices, but are themselves imbued with implicit and explicit gender, race, sexual and national meanings (Pyke \& Johnson, 2003; K. A. Martin, 2009). Actors do not make truly free choices, but they do express individual agency through the cultural values, political projects, and personal intentions they embrace (or resist). Society itself is a recurring human accomplishment (Connell, 2002).

The historicity emphasized by this institutional approach to gender also makes it meaningful to ask not only when but how specific structural gender relations become "deinstitutionalized," as Cherlin (2004) has argued in the case of contemporary American marriage. Feminists have explored the active reinstitutionalization of gender on fundamentally different cultural and material bases, not only in the United States (Goldin, 2006) but also transnationally (Cha \& Thebaud, 2009; Connell, 2008; Peterson, 2005) and in other specific locales, such as postsocialist states (Adler, 2004; Gal \& Kligman, 2000; Rudd, 2000). Particularly in studies of fatherhood, gender research has emphasized both the evidence of change in individuals and families (Coltrane, 2004; Townsend, 2003 ) and the institutional obstacles to remaking fatherhood on significantly more egalitarian terms (Hobson \& Fahlen, 2009; Lister, 2009). The risk remains that changes in gender relations become framed as the inevitable outcome of a single force like modernization, rather than as objectives of struggles that are typically contradictory in their processes and results.

\section{Contestation and Change}

A gender analysis that is self-consciously attentive to both structure and agency explores the processes of contradiction and contention in change over time (Allen, 2001; Coltrane, 2004; Coontz, 2005; Risman, 2009). Rather than individualizing culture schemas as personal attitudes or dehistoricizing cultural demands as monochromatically traditional, an institutional approach to gender analysis defines culture as a powerful force operating at all levels, but one that is locally specific and contested. For example, gender as a category does not just passively exist but must be defined by state action. In the United States, the first challenges to laws limiting marriage to "a man" and "a woman" came at the margins of these gender categories. Existing marriages with transsexual partners had to be validated or invalidated by American courts deciding what is "'a man"' and "a woman," just as earlier courts had ruled on who belonged to which racial categories. The state-by-state inconsistency of these legal definitions of gender underlined how arbitrary they were, as those rules defining racial categories for the purpose of preventing miscegenation also had been, which helped courts to see them as unconstitutional (Lenhardt, 2008). Relations of gender and sexual inequality also have inspired collective resistance to the state on family issues, as in LGBT movements' direct efforts to eliminate the gender specificity of the right to marry the person of one's choice (Taylor, Van Dyke, \& Anderson, 2009).

At the macrolevel, culture appears as discourses of commonsense, appropriateness, and normality - what have been termed "ideologies" and "cultural models" (cf. Cherlin, 2009, on "expressive individualism"). Pascale (2007) showed how individuals made use of macrolevel race and gender discourse in micro ways, by defining who they were in terms of what could be taken for granted about them. Attention to cultural discourse thus provided her a context for understanding accountability (a key term in an interactional understanding of doing gender) in more historically and locally situated terms. This approach has rejected the traditional-modern dichotomy and, instead, has tried to expose the various intensifications and reformulations of cultural norms that follow no one linear, progressive path (Armstrong, 2003; Macdonald, 2009; Wade, 2009).

For example, despite their common selfdefinition as modern, the United States and Western European countries differ strikingly in the common sense expressed in their public 
discourses about gender and families, and their policy changes have sometimes come from contradictory directions. For example, Jenson (2008) argued that, in the wake of feminist movements as well as economic change, the current policy thinking of the European Union has shifted to privilege "the child and its parents" rather than "the worker and his dependents." Although strikingly less gendered, this new model directs attention away from the elderly to focus instrumentally on children in terms of developing human capital rather than either achieving gender equality or meeting human needs.

Although stressing human capital and deferring to the demands of the market is a long institutionalized (albeit highly problematic) U.S. norm, contestations in actual American family policy have been sharply divided by class. More affluent families get framed by a discourse of making policy more "family friendly" (Jacobs \& Gerson, 2004; Stone, 2007). Poor families get framed as needing more "work-discipline" and paternal engagement and influence (Christopher, 2004; Collins \& Mayer, in press). Haney and March (2003) showed how sharply policymakers' understandings of fathers as disciplinarians and income providers diverged from the caring engagement poor women themselves want from men in relation to their children. Problematizing such market-driven demands has been essential to an institutional approach to gender, which puts contestations within families and between families and employers into the context of current and future changes in employment relations for both men and women (Moen \& Roehling, 2004). For example, neither women nor men can easily resist occupational demands for overwork, but institutional demands for long hours have reinforced gender-specific inequalities (Jacobs \& Gerson). Husbands' longer hours pushed their wives down in as well as out of the labor force (Cha, 2010), and mothers' longer hours led them unwillingly to "opt out" of career tracks (Stone).

An institutional approach sees tension and contradiction in gender expectations within and across sites as characteristic rather than exceptional, both historically (M. Adams, 2007; Smock, 2004) and in the present (Gerson, 2002; Sullivan, 2004). P. Y. Martin (2003b) emphasized how all institutions rely on conscious discourses of legitimacy and unconscious routine practices, both of which can be challenged and transformed, but which often operate along separate tracks. Thus inconsistency between discursively legitimate claims ("we share household labor equally") and the routines of practice (who does what and when) should be expected within and among individuals as well as across social locations such as race and class. Rather than a "stalled revolution," this represents the predictably inconsistent nature of the circuits connecting household labor with other institutional sites (Jenkins-Perry \& Claxton, 2009; Lang \& Risman, 2007; Sullivan, 2004).

Institutional analyses combining the macrostructures of definitional and sanctioning authority with the local level of implementation and resistance have been particularly fruitful when they have simultaneously highlighted individual and collective agency as well as state power. For example, U.S. states' efforts to impose their definitions of gender-appropriate roles on the categories of man and woman and husband and wife by emphasizing gender difference as the means to "healthy relationships" have encountered local resistance, as Heath (2009) showed in her study of a state-sponsored relationship training course in a conservative state in which lesbian couple participated without local objection. A comparison between the resistance strategies available to and used by American and Dutch mothers confronting state case workers highlighted the interplay of nationally specific cultures and state regulatory powers in making gender-based claims effective (Korteweg, 2006). Research that brings in the relations among gendered institutions as such, not only looking at identities and interactions within families, will continue to offer family scholars an important tool for exposing such contradictions and explaining gender and family change.

\section{INTERSECTIONAL ANALYSIS: LOCATIONAL AND RELATIONAL MODELS}

In the past decade, gender analysts have theorized more specifically how social structures, political discourses, interpersonal practices, and individual experiences of inequality are shaped not by gender alone but in interaction with race, class, age, sexuality, disability, and other relations of inequality (Ferree, 2009; Few, 2007; Hancock, 2007; McCall, 2005; McDowell \& Fang, 2007). The long and fruitful tradition of feminist scholarship by women of color provided the base on which current theory has built. 
Despite differences in specifics, any perspective is today called intersectional if it takes multiple relations of inequality as the norm, sees them as processes that shape each other, and considers how they interactively define the identities and experiences - and thus analytic standpoints - of individuals and groups (for reviews, see Choo \& Ferree, 2010; Davis, 2008; Hancock, 2007; McCall, 2005). Although feminist research made intersectional gender analyses possible, this perspective has also been fruitfully challenged and enriched by queer theory (Danby, 2007; Goldberg, 2009) and by studies of race/ethnicity, colonialism, and citizenship (for reviews, see Few, 2007; Mahalingham et al., 2009; McDowell \& Fang, 2007). Intersectional gender research has continued to share with feminist research a compelling interest in understanding inequalities (rather than differences) and identifying the potential for change in (rather than adjustment to) the status quo (Allen, 2001).

Although gender scholars have enthusiastically embraced intersectionality, the very ubiquity of the term hides the variety of meanings it has carried (Davis, 2008; Hancock, 2007; McCall, 2005). One significant distinction is between locational and the relational versions of intersectional analysis (Choo \& Ferree, 2010; Ferree, 2009).

\section{Locational Intersectionality}

The locational approach derives from thinking of intersections as defining groups (Crenshaw, 1989) and draws strongly on feminist standpoint theory (McGraw, Zvonkovic, \& Walker, 2000). A focus on intersectional locations emphasizes the identity categories and social positions that are found when multiple forms of subordination co-occur (e.g., poor, Black, single) and makes particular efforts to bring the standpoint of such marginalized persons and groups into the research design. Studies of lesbian mothers (Goldberg, 2009; Mamo, 2007), of urban women's experiences with welfare rules and family poverty (Collins \& Mayer, in press; Haney \& March, 2003), and of immigrant domestic workers (Hondagneu-Sotelo, 2001; Parrenas, 2001) not only have illuminated what these socially devalued individuals face, but also used their standpoint theoretically to gain insights into the workings of the intersectional systems of disadvantage.
Unfortunately, the locational emphasis on giving voice to those who are in positions of oppression has also contributed in practice to what Hancock (2007) called a "content specialization" interpretation of intersectionality: a substantive focus on the study of multiply marginalized groups in isolation from broader systems. Moreover, approaches to disadvantaged groups that fail to bring the standpoint of the multiply marginalized to the center of the analysis lose the essential critical edge of intersectionality, continuing to frame group difference in terms of social problems as seen from the centers of power. Such tacit functionalism may be especially pronounced when researchers impose a traditional-modern dichotomy on their data.

Allendorf (2009) illustrated the value of shifting the normative lens of the discipline away from identifying poor mothers in relation to problems from which they need rescue. She studied pregnant women's empowerment and maternal health in South Asia not only in relation to familiar issues of illiteracy, poverty, and family violence but also by bringing in variation in what the women thought important: the love and trust they had from and for husbands and mothers-in-law. Hertz (2006) used the standpoint of women who chose single motherhood to explore how American families were changing. M. Nelson (2006) used the economic struggles of rural White workingclass single mothers to "make do" as a way of getting at both the cross-institutional work of organizing material survival and the class and gender discourses that made women's choices of whom they consider family meaningful. This feminist emphasis on voice, standpoint, and critical analysis is essential to locational analyses of intersectionality worthy of the name.

\section{Relational Intersectionality}

Framing intersectionality as relations begins by identifying the processes, such as dichotomizing gender and racializing selected ethnicities, that interact to produce dynamic and complex patterns of inequality for everyone, not merely the most disadvantaged (Hancock, 2007; McCall, 2005; Walby, 2009). Struggles and conflicts, rather than groups, are the preferred focus of study in this approach because these are understood as both ubiquitous and informative. For example, M. Adams (2001) looked at a 
"family values" campaign of the 19th century to understand what was contentious over time in American gender and family discourse, and Hancock (2004) focused on tracing the development of political discourses demeaning African American women as "welfare queens" as the context in which poor women attempted to resist such attributions (Haney \& March, 2003).

The relational approach has emphasized that individuals contend with both institutionalized practices and cultural discourses. Pascale (2007, p. 48) studied how individuals both used and contested "commonsense" about race, gender, and class in making their own identities meaningful, treating the meaning of "difference as strategic and positional, and of identity as mobile and performative.' In this light, K. A. Martin (2009) explored the discourse of heteronormativity in childrearing and Kane (2006) looked at the struggles between children and parents over gender-nonconforming behaviors. The conflict between middle-class motherhood and career success emphasized in American culture (Dillaway \& Paré, 2008; Kuperberg \& Stone, 2008) was found not to be reflected in any similarly oppositional relationship for individual womens' self concepts (McQuillan, Greil, Shreffler, \& Tichenor, 2008). Connell (2002) spoke not of passive locations but of active gender projects as positioning decision-making individuals in relation to dynamic social structures of oppression and empowerment. McDaniel (2004) uses generation in this way to highlight gendered age relations as intersectional, unequal, contested, and changing.

Many of these studies have stressed how relations of inequality themselves undergo change. For example, the shift to globalized chains of production and the intensification of employer demands for workers' time availability have challenged local gender systems as well as race and class arrangements (Ehrenreich \& Hochschild, 2003; Peterson, 2005). Relational models of intersectionality have been able to incorporate the institutional emphasis on active circuits of power that work through both material and discursive means by researchers' focus on specific struggles. They have often studied family outside the family: For example, some have explored how state support and women's childcare labor is negotiated in welfare offices by caseworkers and clients in different countries (Haney, 2000; Korteweg, 2006) and across U.S. locales (Hays, 2002; Mayer, 2007), how and which employees claimed rights for family time from employers (Armenia \& Gerstel, 2006), and when and why employers resisted specific claims and claimants for leaves (Albiston, 2007; Clawson, Gerstel, \& Huyser, 2007).

\section{Gender, Men, and Masculinity}

Both types of intersectional analysis have helped to make family research truly about gender rather than just about women, directing attention to men as actors with gendered subjectivities and to gendered relations of masculinity operating in relation to other inequalities. Locational studies of masculinity as intersectional have proven useful to family studies in several ways. They have given voice to men who may be otherwise overlooked, for example, by showing the egalitarianism in workingclass compared to professional men's ideals and practices of family participation in Japan (Ishii-Kunz, 2009) and in the United States (Shows \& Gerstel, 2009) or revealing how gay fathers understand the challenges of being fathers in a heterosexist society (Berkowitz \& Marsiglio, 2007; Stacey, 2005). They have highlighted contradictions, as when Townsend (2003) explored the standard normative case of middle-class American masculinity to pull out the elements of self-concept not reducible to the single relationship of breadwinning and to highlight inconsistencies among these parts. And they have identified men's own family change projects, even among conservative Christians who are more or less consciously remaking patriarchy for themselves at the microlevel (Wilcox, 2004). The best locational intersectional research has situated individual men's struggles with masculinities (their gender projects) in relation to macrolevel changes in how masculinity is institutionalized, such as the shift from local bourgeois masculinity (with church and community involvement linked to men's career advancement) to the rootlessly transnational corporate masculinity now seen among elites (Connell, 2008; Peterson, 2005).

The relational perspective on intersectionality has proven particularly fruitful for unpacking the multiple layers of both oppression and privilege in action for men and boys. For example, relational gender analysis has been used to understand how racialized masculinity was used by both European American and African American teachers to stratify African 
American boys in a public school (Ferguson, 2000). It has also helped to explain the political hostility in France and the United States among working-class men toward people of color (Lamont, 2000). As Lamont showed, French men took up media depictions of immigrants as "too patriarchal" and U.S. White men saw Black families as "lacking male authority," but both used the framing of others as having the wrong sort of families to buttress their own selfrespect as fathers. Hobson (2002) considered the various national and local frameworks shaping the process of "making men into fathers" and Hook and Calasanti (2008) pointed to the contradictions in male single parents' dual projects of doing masculinity and mothering.

Studies of how discourses about gender (Gal \& Kligman, 2000) and family (Haney \& Pollard, 2004) have been used to interpret and manage social change for both men and women are another type of relational analysis of intersectionality that has been particularly important in the past decade. Gal and Kligman used data from postsocialist Eastern Europe to indicate how discourses of male authority and practices of control over relations of reproduction carried particular weight in times of political uncertainty. Espiritu (2001) showed how economically marginalized immigrant families in the United States used control over their daughters' sexuality as a way of claiming moral superiority to the host culture, a claim that daughters sometimes shared and sometimes contested. Using comparisons of Dutch and American discourses about teenage sexuality, Schalet (2000) demonstrated how the American "raging hormones" interpretation fed into authorities' efforts to suppress sexual expression, to control boys as " "predators," and to protect girls as their helpless " "prey," whereas the Dutch view of "readiness" promoted more self-regulation by both boys and girls. Rudd (2000) described both men and women in the former East Germany as sharing an understanding of their family relations as having been utterly undercut by the new capitalist order. Contested discourses over "traditional marriage" in the United States and "veiling" in Western Europe provide other rich examples of intersectional relationships of inequality in struggles over the role of the state in regulating gender, sexuality, and culturally valued family practices (Heath, 2009; Rottmann \& Ferree, 2008).
In sum, the difference between the two approaches to intersectionality can best be seen in the degree to which institutional change is central to the analysis. The locational approach is more static: It defines groups a priori as marginalized or privileged and then uses perspectives from these margins to reveal relationships of power at the center and expose relations across a list of elements of inequality, such as race, class, gender, sexuality, and age. The relational approach foregrounds struggles that reveal the multidimensional organization of power and privilege. It draws on the discourses of more and less powerful social actors to critically engage with the terms of debate in such institutional sites as scholarship, policy making, and popular culture. Studies of even privileged White men and middle-class masculinity are intersectional to the extent that they ask questions about how structural changes in class and gender relations have encouraged men and women to embrace different forms of family, whether gay fathers in Los Angeles "mothering" special needs children (Stacey, 2005) or elite fathers left behind to pay the bills for cross-national "helicopter" mothers supervising the education of their children (Mahalingham et al., 2009).

Both relational and locational intersectional analyses complement each other and enrich a gender perspective, especially when they balance attention to structures of inequality with a concern for agency and voice. Some have pointed to the danger in locational attention to diversity in that it makes cultures appear too static, homogeneous, and well bounded (Hancock, 2007; McDowell \& Fang, 2007). Others have argued that the relational approach risks understating the significance of historically institutionalized collective identities as standpoints for a critical view of inequalities (Anderson, 2005; Davis, 2008). Yet intersectional analysis of either kind implies looking at privilege and oppression as inherently multiple and contradictory and so opens up new opportunities for critique and change.

\section{CONSIDERING CAREWORK AS INSTITUTIONALLY INTERSECTIONAL}

Carework has long been important to feminist theory because the actual work of care is strongly tied to women, socially devalued, and incontrovertibly vital to society (Folbre, 2001). 
Thinking about care provides an illustration of the challenges for developing a family research agenda more attentive to institutional, intersectional dynamics of gender (England, 2005; Folbre, 2004). Because families are one of the several institutions charged with providing care, gender scholarship will benefit if family research makes a greater effort to investigate caregivers' locational standpoints and relational struggles across multiple sites.

The institutional unraveling of a system of care built on the premise of male breadwinner families has become generally obvious in both Europe and the United States in recent years (Folbre, 2004; Hochschild, 2003). But because states differ, intersectional gender scholarship in the United States and Europe has tended to emphasize different problematics. In the United States, research has followed practice and stressed income deficiencies and market discrimination as major problems for caregivers. In Europe, feminist research has focused on how state policy interacts with personal agency and how time use is institutionally regulated. Both have offered provocative ideas for taking states, markets, families, and communities seriously as macrostructures in the throes of institutional transformation and have begun to consider issues that have long been neglected. Such research points to promising practices with which individual and group struggles can increase the slow drip of social change in the direction of social justice.

\section{American Challenges}

At the heart of the American issues with families as caring institutions is the degree to which a political culture of liberal individualism resists valuing care (Cherlin, 2009; Folbre, 2001). Levitsky (2006) provided an exemplary study of U.S. caregiver support groups that focused on how family caregivers struggle to articulate their demands for more financial and social support against the grain of the discourse, pointing to how state policy, employer actions, local groups, and interpersonal needs shaped these individuals' legal consciousness, that is, their sense of a right relationship between themselves and the state. Legal consciousness was also critical to Albiston (2005), who showed both that employers particularly resisted men's claims for family leave when there was any woman in their household and that the men who persevered won legal support for their struggle to "undo" gender. Challenging the U.S. state to value care work appropriately has led to both research and activism around sick leave, parental leave, and pensions (see, e.g., www.iwpr.org).

Income, a key circuit connecting families and workplaces, is one way to approach the institutional valuation of care and its intersectional inequalities. A new line of research on how income inequality in couples changes over time within a marriage and in society as a whole follows this circuit to expose both material and normative change (Becker, 2008; Winkler, McBride, \& Andrews, 2005; Winslow-Bowe, 2006). Following the circuit of income also points to the discrimination facing mothers in the workplace, which has emerged as a promising topic in recent years. There is now evidence from both labor force data and innovative experimental research (Correll, Benard, \& Paik, 2007) that White women who are perceived to be mothers will be faced with an additional layer of discrimination on top of what they face as women, although not necessarily above what Black women routinely face (Glauber, 2007). Labor force studies have found all fathers got a wage bonus rather than paying a cost, but only non-Black married men earned more when their wives worked fewer hours (Glauber, 2008). Yet for both men and women, work with a caregiving component was paid less than other jobs of similar skill and gender (Budig, England, \& Folbre, 2002).

The income circuit also points to how the wages of paid caregivers have been suppressed by the American discourse pitting caring against earning. Interviews with employers have revealed that they think the quality of care is enhanced by the selective effects of low pay, so that only those who are willing to work "for love" would be willing to do this work (J. Nelson, 2003; Whitaker, 2003). Nonetheless, this underpayment contributed to high turnover, which lowered quality of care through disruptions of personal relations. Pitting love against money as exclusive motivations also has been found to contribute to the devaluation of foster mothers, often working-class women (Swartz, 2004) and to the racialization of elder care (Dodson \& Zincavage, 2007). Yet care workers have also actively contested this devaluation, sometimes successfully (Misra, 2003; Macdonald, 2010; Tuominen, 2003). 


\section{European Challenges}

The European climate for debates about caregiving is very different, because there has been a long history of institutionalized state protections and economic provision to support mothers' caregiving work outside the marketplace (Morgan \& Zippel, 2003). Using market mechanisms to provide care is deeply controversial, as the public debate over employing maids in Sweden has shown (Bowman \& Cole, 2009). The relatively smaller significance of markets and unpaid community labor in providing essential care work makes the state's role in the regulation of time - the institutionalization of normal working hours, days, weeks, and years - an exceptionally interesting circuit to follow.

On the one hand, there has been a partially successful feminist struggle to bring norms of gender equality into the European Union's principles and policies for care leave. One very visible outcome of this has been the push to make fathers also be legally granted (and sometimes even be required to take) paid time away from their jobs for childrearing (Hobson \& Fahlen, 2009). The degree to which men have taken available fatherhood leaves varies, depending on the details of the specific policy, national discourses around gender equality, and specific workplace cultures (Hobson \& Fahlen; Lister, 2009). Time use data have thus been of particular importance for European research linking macropolicies and father engagement (Sullivan, Coltrane, McAnnally, \& Altintas, 2009). Unfortunately, the push for state institutionalization of engaged fatherhood may also feed intolerance by framing European values as modern and egalitarian in opposition to those of immigrant groups, presented as uniformly oppressive and dangerous (Lamont, 2000; Lister).

On the other hand, there have been economic and political shifts in the European Union toward more intensive engagement of all adults in paid labor (activation) and toward less regulation of hours and conditions of work (flexibilization), with vastly unequal consequences for women and men and among women in different member countries (Daly \& Rake, 2003). Legally fixed retirement ages, vacation days, school calendars, and shopping hours are more inflexible in Europe than in the United States. These rules combine with more explicitly gendered state policies of maternity and parental care leaves to set particular parameters for how family members coordinate care that vary by specific policy configuration (Cooke \& Baxter, 2010; Morgan, 2006). Some European feminists have looked critically at state time policies that endorse the principle of fostering work-life balance, suggesting that women's own needs and perspectives have gotten short shrift in the scramble to simultaneously increase economic productivity over the life course and promote fertility (Lewis \& Campbell, 2008; Stratigaki, 2004). But they have also begun important theoretical work to integrate structure and agency in this context, particularly through a capabilities approach (Hobson \& Fahlen, 2009; Lewis \& Giullari, 2005).

Despite drastic recent changes, policy histories also matter for entrenching cultural norms. For example, the division of household labor in once-socialist East Germany continued after unification to reflect its different experiences with gender than West Germany (Cooke, 2007), and East German women "stubbornly" have resisted conforming their family behaviors to the Western norms (Adler, 2004). Hagemann (2006) drew attention to the "time politics" of West German institutions, particularly how the hours kept by schools, shops, and workplaces limited women's options. A more generalized view of time as a circuit connecting gender relations among institutions and over the life course awaits development.

A truly intersectional view of time and income practices would also need to consider states, markets, communities, and families as relating across national borders outside the rich democracies. Some countries, such as the Philippines, actively encouraged the migration of both mothers and fathers to provide remittances and thus educational opportunities to their children (Parrenas, 2005). Other states, such as Italy, have recruited migrants to provide home-based elder care and encouraged Italian women to take paid jobs and men to take parental leaves (Naldini \& Saraceno, 2008). Models of family support and gender equality that cannot be generalized across countries are neither sustainable nor fair (Hassim, 2008).

\section{A FORWARD-LOOKING CONCLUSION}

Gender and family change is ongoing, but for which people and for what relations any particular change constitutes a crisis or an opportunity is and should be debatable. The circuits of time and income traced in relation to care are only one example of what such politics may entail. Many 
other cross-cutting multi-institutional issues with substantial implications for families (such as adolescent sexuality, reproductive rights, or interpersonal violence) could be used to illuminate the power of an institutional and intersectional gender analysis for family researchers, and also provide arenas in which family studies has much to contribute to understanding gender and other material and discursive inequalities. But it is important to recognize that, in a context of struggle, not every change is progress and nearly all changes have differential effects on those who are more or less powerful and privileged. This is why studying struggles and their outcomes is so important and yet so difficult.

Some changes point to the institutionalization and intensification of relations of inequality. For example, intensified economic competition, the export of many manual labor jobs to low-wage countries, and a set of winner-take-all rules in American capitalism certainly have played a role in intensifying demands on middle-class mothers to cultivate their children's educational advantages over others. These heightened maternal work expectations have been evident both from birth to age 3 (Macdonald, 2009) and after the children are in school (Lareau, 2003). The investment in children demanded of "good" mothers today has not only become about actual care work but at least in part demands symbolic sacrifice, for example, in medically irrelevant refusals of a glass of wine by pregnant women (Armstrong, 2003). "Bad mothers," a powerfully racialized group, have become subjected to intensified strategies of social control (Flavin, 2009; Springer, in press), and young Black men's family relations are disrupted by extremely high levels of police surveillance (Goffman, 2009). Poor women have been put in a position in which they must choose between violating standards of good care (e.g., making sure a child receives needed medical attention) and breaking the rules for keeping their jobs or state benefits (Collins \& Mayer, in press). Rather than showing a single evolution toward greater gender equality in modern societies, these studies have revealed the contested raceand class-specific restructuring of gender relations specific to the contemporary United States. Although European societies face their own struggles over declining fertility and increasing immigration, they have been more open than the United States to rewarding care work and accommodating same-sex relationships.
The search for practices to transform gender relations in and through the family as an institution thus points to a continuing need for research considering the political and economic contexts in which families are situated, neither suggesting the United States as an invisible normative standard nor erasing the difference that context makes for intersectional struggles. If gender and family scholars hope to do justice to the real diversity of gender strategies and struggles, research should locate behaviors and norms in historical or policy contexts, and the framing of a traditional-modern dichotomy should be avoided, like the equally theoretically unsupportable term gender role. The circuits among family-state-market-community should be scrutinized as they flow in multiple directions, with both stabilizing and destabilizing effects on intersectional inequalities in various institutional sites. Much more comparative research, especially among the rich democracies, is needed to untangle the relations between institutions and practices in this era of change, not only at the policy level or in regard to material resources (Cooke \& Baxter, 2010; Gornick \& Meyers, 2009), but in the ways that macrolevel discourses convey the priorities of the powerful from the top down and become objects of struggle from the bottom up (Cha \& Thebaud, 2009).

An analysis of families, therefore, that takes seriously the institutional circuits and intersectional inequalities in which gender is everywhere involved and attempts to understand their operations over time cannot be a depoliticized science. As the studies reviewed here are, such research can be rigorous in its methods and theoretically well defined. But insofar as analyzing gender attempts to reveal power as an active, changing relationship, such research will contribute to either doing or undoing the relations among institutions through which inequalities flow. It is thus political in the broadest sense. Although feminist researchers may not find this insight particularly novel, I suggest that the best gender research of this decade has laid the groundwork for an intersectional, institutional agenda where contradiction, contestation, and change is central to studying families.

\section{Note}

This article could not possibly have been written without the extensive feminist support and substantive and editorial suggestions generously offered to me by Lisa D. Brush, Lynn Prince Cooke, Cameron Macdonald, Joya Misra, and Barbara J. Risman. I cannot begin to thank them 
sufficiently. My thanks also go to Naomi Gerstel, Lynne Haney, Sarah Kaiksow, Victoria Mayer, Julia McQuillan, Margaret Nelson, Ann Orloff, and Kristen Springer for their encouraging comments and constructive critiques on earlier drafts. Wendy Christensen was, as usual, a crucial and intelligent editorial assistant. Finally, my appreciation goes to my husband, Don, whose practical support and sympathetic patience have buoyed me as I have struggled with the difficult task of imposing some degree of order on this vast and diverse literature.

\section{REFERENCES}

Adams, J., Clemens, E., \& Orloff, A.S. (Eds.). (2005). Remaking modernity: Politics, history and sociology. Durham, NC: Duke University Press.

Adams, M. (2007). Women's rights and wedding bells: 19th-century pro-family rhetoric and (re)enforcement of the gender status quo. Journal of Family Issues, 28, 501-528.

Adler, M. (2004). Childfree and unmarried: Changes in the life planning of young East German women. Journal of Marriage and Family, 66, 1170-1179.

Albiston, C. (2005). Bargaining in the shadow of social institutions: Competing discourses and social change in workplace mobilization of civil rights. Law and Society Review, 39, 11-50.

Albiston, C. (2007). Institutional perspectives on law, work, and family. Annual Review of Law and Social Science, 3, 397-426.

Allen, K. R. (2001). Feminist visions for transforming families: Desire and equality, then and now. Journal of Family Issues, 22, 791-809.

Allendorf, K. (2009). The quality of family relationships, women's agency, and maternal and child health in India. Unpublished dissertation, University of Wisconsin-Madison.

Anderson, M. (2005). Thinking about women: A quarter-century's view. Gender and Society, 19, $337-355$.

Armenia, A., \& Gerstel, N. (2006). Family leaves, the FMLA and gender neutrality: The intersection of race and gender. Social Science Research, 35, $871-891$.

Armstrong, E. (2003). Conceiving risk, bearing responsibility: Fetal alcohol syndrome and the diagnosis of moral disorder. Baltimore: Johns Hopkins University Press.

Becker, T. (2008). When equality is not enough: The (lack of) stability in relative earnings within marriage (Dissertation). Available from ProQuest Dissertations and Thesis database (AAT 3349120).

Berk, S. F. (1985). The gender factory. New York: Plenum Press.

Berkowitz, D., \& Marsiglio, W. (2007). Gay men: Negotiating procreative, father and family identities. Journal of Marriage and Family, 69, 366-381.

Bittman, M., England, P., Sayer, L., Folbre, N., \& Matheson, G. (2003). When does gender trump money? Bargaining and time in household work. American Journal of Sociology, 109, 186-214.

Blair-Loy, M. (2003). Competing devotions: Career and family among women executives. Cambridge, MA: Harvard University Press.

Blume, L. B., \& Blume, T. W. (2003). Toward a dialectical model of family gender discourse: Body, identity, and sexuality. Journal of Marriage and Family, 65, $785-794$.

Bowman, J. R., \& Cole, A. M. (2009). Do working mothers oppress other women? The Swedish "maid debate" and the welfare state politics of gender equality. Signs: Journal of Women in Culture and Society, 35, 157-184.

Brush, L. D. (2003). Gender and governance. Walnut Creek, CA: AltaMira Press.

Budig, M., England, P., \& Folbre, N. (2002). Wages of virtue: The relative pay of care work. Social Problems, 49, 455-473.

Buss, D., \& Herman, D. (2003). Globalizing family values: The Christian right in international politics. Minneapolis: University of Minnesota Press.

Calasanti, T., \& Slevin, K. F. (2006). Age matters: Realigning feminist thinking. New York: Routledge.

Cancian, F., Kurz, D., London, A., Reviere, R., \& Tuominen, M. (Eds.). (2002). Child care and inequality: Rethinking carework for children and youth. New York: Routledge.

Cha, Y. (2010). Reinforcing separate spheres: The effect of spousal overwork on men's and women's employment in dual-earner households. American Sociological Review, 75, 303-329.

Cha, Y., \& Thebaud, S. E. (2009). Labor markets, breadwinning, and beliefs: How economic context shapes men's gender ideology. Gender and Society, 23, 215-243.

Cherlin, A. (2004). The deinstitutionalization of American marriage. Journal of Marriage and Family, 66, 848-861.

Cherlin, A. (2009). The marriage-go-round: The state of marriage and the family in America today. New York: Knopf.

Choo, H. Y., \& Ferree, M. M. (2010). Practicing intersectionality in sociological research: A critical analysis of inclusions, interactions and institutions in the study of inequalities. Sociological Theory, 28, 147- 167 .

Christopher, K. (2004). Welfare as we (don't) know it: A review and feminist critique of welfare reform research in the United States. Feminist Economics, 10, $143-171$.

Clawson, D., Gerstel, N., \& Huyser, D. (2007). Doing, negotiating, and contesting work time: An analysis of class and gender in four medical occupations. In Juravich, T. (Ed.), The future of work (pp. 163-181). Amherst: University of Massachusetts Press. 
Collins, J., \& Mayer, V. (in press). With both hands tied: Welfare and motherwork. Chicago: University of Chicago Press.

Coltrane, S. (2001). Marketing the marriage 'solution': Misplaced simplicity in the politics of fatherhood. Sociological Perspectives, 44, 387-418.

Coltrane, S. (2004). Elite careers and family commitment: It's (still) about gender. Annals of the American Academy of Political and Social Science, 596, 214-220.

Coltrane, S., \& Adams, M. (2003). The social construction of the divorce "problem": Morality, child victims, and the politics of gender. Family Relations, 52, 21-30.

Coltrane, S., \& Adams, M. (2008). Gender and families (2nd ed.). Lanham, MD: Rowman and Littlefield.

Connell, R. W. (2002). Gender. Malden, MA: Blackwell.

Connell, R. W. (2008). Men, masculinity and gender justice. In I. Lenz, C. Ullrich, \& B. Fersch (Eds.), Gender orders unbound: Globalization, restructuring and reciprocity (pp. 51-68). Farmington Hills, MI: Budrich.

Cooke, L. P. (2006). "Doing gender" in context: Household bargaining and the risk of divorce in Germany and the United States. American Journal of Sociology, 112, $442-472$.

Cooke, L. P. (2007). Persistent policy effects on gender equity in the home: The division of domestic tasks in reunified Germany. Journal of Marriage and Family, 69, 930 -950.

Cooke, L. P., \& Baxter, J. (2010). "Families" in international perspective: Comparing institutional effects across western societies. Journal of Marriage and Family, 72, 516-536.

Coontz, S. (2005). Marriage, a history: From obedience to intimacy or how love conquered marriage. New York: Viking.

Correll, S. J., Benard, S., \& Paik, I. (2007). Getting a job: Is there a motherhood penalty? American Journal of Sociology, 112, 1297-1338.

Crenshaw, K. W. (1989). Demarginalizing the intersection of race and sex: A Black feminist critique of antidiscrimination doctrine, feminist theory and antiracist politics. University of Chicago Legal Forum, 139-167.

Daly, M., \& Rake, K. (2003). Gender and the welfare state: Care, work and welfare in Europe and the USA. Malden, MA: Polity Press.

Danby, C. (2007). Political economy and the closet: Heteronormativity in feminist economics. Feminist Economics, 13, 29-53.

Davis, K. (2008). Intersectionality as buzzword: A sociology of science perspective on what makes a feminist theory successful. Feminist Theory, 9, $67-85$.

Deutsch, F. (2007). Undoing gender. Gender and Society, 21, 106-127.
Dillaway, H., \& Paré, E. (2008). Locating mothers: How cultural debates about stay-at-home versus working mothers define women and home. Journal of Family Issues, 29, 437 - 464.

Dodson, L., \& Zincavage, R. (2007). It's like a family: Caring labor, exploitation and race in nursing homes. Gender \& Society, 21, 905-928.

Ehrenreich, B., \& Hochschild, A. R. (2003). Global woman: Nannies, maids, and sex workers in the new economy. New York: Metropolitan Books.

England, P. (2005). Emerging theories of care work. Annual Review of Sociology, 31, 381-399.

Espiritu, Y. L. (2001). "We don't sleep around like White girls do": Family, culture, and gender in Filipina American life. Signs: Journal of Women in Culture and Society, 26, 415-440.

Fenstermaker, S., \& West, C. (2002). Doing difference: Inequality, power and institutional change. New York: Routledge.

Ferguson, A. A. (2000). Bad boys: Public schools in the making of Black masculinity. Ann Arbor: University of Michigan Press.

Ferree, M. M. (1990). Beyond separate spheres: Feminism and family research. Journal of Marriage and the Family, 52, 866-884.

Ferree, M. M. (2009). Inequality, intersectionality and the politics of discourse: Framing feminist alliances. In E. Lombardo, P. Meier, \& M. Verloo (Eds.), The discursive politics of gender equality: Stretching, bending and policy-making (pp. 84-101). London: Routledge.

Few, A. (2007). Integrating Black consciousness and critical race feminism into family studies research. Journal of Family Issues, 28, 452-473.

Flavin, J. (2009). Our bodies, our crimes: The policing of women's reproduction in America. New York: New York University Press.

Folbre, N. (2001). The invisible heart: Economics and family values. New York: New Press.

Folbre, N. (2004). Family time: The social organization of care. New York: Routledge.

Fox, G. L., \& Murry, V. M. (2000). Gender and families: Feminist perspectives and family research. Journal of Marriage and the Family, 62, $1160-1172$.

Gal, S., \& Kligman, G. (2000). The politics of gender after socialism: A comparative-historical essay. Princeton, NJ: Princeton University Press.

Gerson, K. (2002). Moral dilemmas, moral strategies and the transformation of gender: Lessons from two generations of work and family change. Gender and Society, 16, 8-28.

Glauber, R. (2007). Marriage and the motherhood wage penalty among African Americans, Hispanics, and Whites. Journal of Marriage and Family, 69, $951-961$.

Glauber, R. (2008). Race and gender in families and at work: The fatherhood wage premium. Gender and Society, 22, 8-30. 
Goffman, A. (2009). On the run: Wanted men in a Philadelphia ghetto. American Sociological Review, 74, 339-357.

Goldberg, A. (2009). Lesbian parents and their families: Complexity and intersectionality from a feminist perspective. In S. Lloyd, A. Few, \& K. Allen (Eds.), Handbook of feminist family studies (pp. 108-120). Thousand Oaks, CA: Sage.

Goldin, C. (2006). The quiet revolution that transformed women's employment, education, and family. American Economic Review, 96, 1-21.

Gornick, J., \& Meyers, M. (2009). Gender equality: Transforming family divisions of labor. New York: Verso.

Gupta, S. (2006). The consequences of maternal employment during men's childhood for their adult housework performance. Gender and Society, 20, $60-86$.

Gupta, S. (2007). Autonomy, dependence or display? The relationship between married women's earnings and housework. Journal of Marriage and Family, 69, 399-417.

Hagemann, K. (2006). Between ideology and economy: The "time politics" of child care and public education in the two Germanys. Social Politics, 13, 217-260.

Hancock, A. (2004). The politics of disgust: The public identity of the welfare queen. New York: New York University Press.

Hancock, A. (2007). When multiplication doesn't equal quick addition: Examining intersectionality as a research paradigm. Perspectives on Politics, $5,63-79$.

Haney, L. (2000). Global discourses of need: Mythologizing and pathologizing welfare in Hungary. In M. Burawoy (Ed.), Global ethnography (pp. 48-73). Berkeley: University of California Press.

Haney, L., \& March, M. (2003). Married fathers and caring daddies: Welfare reform and the discursive politics of paternity. Social Problems, $50,461-481$.

Haney, L., \& Pollard, L. (Eds.). (2004). Families of a new world: Gender, politics, and state development in a global context. New York: Routledge.

Harrington Meyer, M., \& Herd, P. (2007). Market friendly or family friendly? The state and gender inequality in old age. New York: Russell Sage Foundation.

Hassim, S. (2008). Global constraints on gender equality in care work. Politics and Society, 36, $388-402$.

Hays, S. (2002). Flat broke with children: Women in the age of welfare reform. New York: Oxford University Press.

Heath, M. (2009). State of our unions: Marriage promotion and the contested power of heterosexuality. Gender and Society, 23, $27-48$.
Hertz, R. (2006). Single by chance, mothers by choice: How women are choosing parenthood and creating the new American family. New York: Oxford University Press.

Hill, S. (2005). Black intimacies: A gender perspective on relationships and families. Walnut Creek, CA: AltaMira Press.

Hobson, B. (Ed). (2002). Making men into fathers: Men, masculinities and the social politics of fatherhood. Cambridge: Cambridge University Press.

Hobson, B., \& Fahlen, S. (2009). Competing scenarios for European fathers: Applying Sen's agency and capabilities framework to work-life balance. Annals of the American Academy of Political and Social Science, 64, 214-243.

Hochschild, A. R. (2003). The commercialization of intimate life: Notes from home and work. Berkeley: University of California Press.

Holstein, J., \& Gubrium, J. (1999). What is family? Further thoughts on a social constructionist approach. Marriage and Family Review, 28, 3-20.

Hondagneu-Sotelo, P. (2001). Doméstica: Immigrant workers cleaning and caring in the shadows of affluence. Berkeley: University of California Press.

Hook, J., \& Calasanti, S. (2008). Gendered expectations? Reconsidering single fathers' childcare time. Journal of Marriage and Family, 70, 978-990.

Howell, J. (2007). Gender and civil society: Time for cross-border dialogue. Social Politics, 4, $415-436$.

Ishii-Kunz, M. (2009). Working-class fatherhood and masculinities in contemporary Japan. In S. Lloyd, A. Few, \& K. Allen (Eds.), Handbook of feminist family studies (pp. 177-191). Thousand Oaks, CA: Sage.

Jacobs, J., \& Gerson, K. (2004). The time divide: Work, family, and gender inequality. Cambridge, MA: Harvard University Press.

Jenkins-Perry, M., \& Claxton, A. (2009). Feminist visions for rethinking work and family connections. In S. Lloyd, A. Few, \& K. Allen (Eds.), Handbook of feminist family studies (pp. 121-133). Thousand Oaks, CA: Sage.

Jenson, J. (2008), Writing women out, folding gender in: The European Union "modernizes" social policy. Social Politics, 15, 131-153.

Jurik, N., \& Siemsen, C. (2009). Doing gender as canon or agenda? Gender and Society, 23, 72 - 75.

Kane, E. (2006). No way my boys are going to be like that! Parents' responses to children's gender nonconformity. Gender and Society, 20, 149-176.

Korteweg, A. (2006). The construction of gendered citizenship at the welfare office: An ethnographic comparison of welfare-to-work workshops in the United States and the Netherlands. Social Politics, $13,313-340$. 
Kuperberg, A., \& Stone, P. (2008). The media depiction of women who "opt out." Gender and Society, 22, 497-517.

Lamont, M. (2000). The dignity of working men: Morality and the boundaries of race, class, and immigration. New York: Russell Sage Foundation.

Lang, M. M., \& Risman, B. J. (2007). A "stalled"' revolution or a still-unfolding one? The continuing convergence of men's and women's roles. Paper prepared for the 10th Anniversary Conference of the Council on Contemporary Families, Chicago.

Lareau, A. (2003). Unequal childhoods: Class, race, and family life. Berkeley: University of California Press.

Lenhardt, R. A. (2008). Beyond analogy: Perez v. Sharp, antimiscegenation law, and the fight for same-sex marriage. California Law Review, 96, $839-902$.

Levitsky, S. (2006). Private dilemmas of public provision: The formulation of political demand for long-term care provision. (Doctoral dissertation). Retrieved from ProQuest Dissertations and Thesis database (AAT 3245607).

Lewis, J., \& Campbell, M. (2008). What's in a name? "Work and family" or "work and life" balance policies in the UK since 1997 and the implications for the pursuit of gender equality. Social Policy and Administration, 42, 524-541.

Lewis, J., \& Giullari, S. (2005). The adult worker model family, gender equality and care: The search for new policy principles and the possibilities and problems of a capabilities approach. Economy and Society, 34, 76-104.

Lister, R. (2009). A Nordic nirvana? Gender, citizenship and social justice in the Nordic welfare states. Social Politics, 16, $242-278$.

Lloyd, S., Few, A. \& Allen, K. (2009). Handbook of feminist family studies. Thousand Oaks, CA: Sage.

Lorber, J. (2005). Breaking the bowls: Degendering and feminist change. New York: Norton.

Macdonald, C. L. (2009). What's culture got to do with it? Mothering ideologies as barriers to gender equity. In J. Gornick \& M. Meyers (Eds.), Gender equality: Transforming family divisions of labor (pp. 411-434). New York: Verso.

Macdonald, C. L. (2010). Shadow mothers: Nannies, au pairs, and the micropolitics of mothering. Berkeley: University of California Press.

Mahalingham, R., Balan, S., \& Molina, K. (2009). Transnational intersectionality: A critical framework for theorizing motherhoods. In S. Lloyd, A. Few, \& K. Allen (Eds.), Handbook of feminist family studies (pp. 69-79). Thousand Oaks, CA: Sage.

Mamo, L. (2007). Queering reproduction: Achieving pregnancy in the age of technoscience. Durham, NC: Duke University Press.

Martin, K. A. (2009). Normalizing heterosexuality: Mothers' assumptions, talk and strategies with young children. American Sociological Review, 74, 190-207.

Martin, P. Y. (2003a). Gender as a social institution. Social Forces, 82, 1249-1274.

Martin, P. Y. (2003b). "Said and done" versus "saying and doing": Gendering practices and practicing gender at work. Gender and Society, $17,342-366$.

Mayer, V. (2007). Contracting citizenship: Shifting public boundaries in the context of welfare reform (Dissertation). Available from ProQuest Dissertations and Thesis database. (AAT 3294077).

McCall, L. (2005). The complexity of intersectionality. Signs: Journal of Women in Culture and Society, 30, 1771-1800.

McDaniel, S. A. (2004). Generationing gender: Justice and the division of welfare. Journal of Aging Studies, 18, $27-44$.

McDowell, T., \& Fang, S. R. S. (2007). Feministinformed critical multiculturalism: Considerations for family research. Journal of Family Issues, 28, $549-566$.

McGraw, L., Zvonkovic, A., \& Walker, A. J. (2000). Studying postmodern families: A feminist analysis of ethical tensions in work and family research. Journal of Marriage and the Family, 62, 68-77.

McQuillan, J., Greil, A., Shreffler, K., \& Tichenor, V. (2008). The importance of motherhood among women in the contemporary U.S. Gender \& Society, 22, 477-496.

Misra, J. (2003). Caring about care. Feminist Studies, 29, 387-401.

Moen, P., \& Roehlinger, P. (2004). The career mystique: Cracks in the American dream. Lanham, MD: Rowman and Littlefield.

Morgan, K. (2006). Working mothers and the welfare state. Stanford, CA: Stanford University Press.

Morgan, K., \& Zippel, K. (2003). Paid to care: The origins and effects of care leave policies in western Europe. Social Politics, 10, 49-85.

Naldini, M., \& Saraceno, C. (2008). Social and family policies in Italy: Not totally frozen but far from structural reforms. Social Policy and Administration, 42, 733-748.

Nelson, J. (2003). The childcare economic conundrum: Quality versus affordability. In K. Moe (Ed.), Women, family, and work: Writings on the economics of gender (pp. 125-141). Malden, MA: Blackwell.

Nelson, M. (2003). The social economy of single motherhood: Raising children in rural America. New York: Routledge.

Nelson, M. (2006). Single mothers "do" family. Journal of Marriage and Family, 68, 781 - 795.

O'Connor, A. (2001). Poverty knowledge: Social science, social policy and the poor in twentiethcentury U.S. history. Princeton, NJ: Princeton University Press. 
Oswald, R. (2002). Resilience within the family networks of lesbians and gay men: Intentionality and redefinition. Journal of Marriage and Family, 64, 374-383.

Parrenas, R. (2001). Servants of globalization: Women, migration and domestic work. Stanford, CA: Stanford University Press.

Parrenas, R. (2005). Children of global migration: Transnational families and gendered woes. Stanford, CA: Stanford University Press.

Pascale, C. (2007). Making sense of race, class and gender: Commonsense, power and privilege in the United States. New York: Routledge.

Peterson, V. S. (2005). How (the meaning of) gender matters in political economy. New Political Economy, 10, 499-521.

Presser, H. (1997). Demography, feminism, and the science-policy nexus. Population and Development Review, 23, 295-331.

Presser, H. (2004). Working in a 24/7 economy: Challenges for American families. New York: Russell Sage Foundation.

Pyke, K., \& Johnson, D. L. (2003). Asian American women and racialized femininities: "Doing gender', across cultural worlds. Gender and Society, 17, 33-53.

Risman, B. J. (2004). Gender as a social structure: Theory wrestling with activism. Gender and Society, 18, 429-450.

Risman, B. J. (2009). From doing to undoing: Gender as we know it. Gender and Society, 23, 81-84.

Rosenfeld, M. J. (2007). The age of independence: Interracial unions, same-sex unions and the changing American family. Cambridge, MA: Harvard University Press.

Rottmann, S., \& Ferree, M. M. (2008). Citizenship and intersectionality: German feminist debates about headscarf and anti-discrimination laws. Social Politics, 15, 481-513.

Rudd, E. (2000). Reconceptualizing gender in postsocialist transformation. Gender and Society, 14, $517-539$.

Schalet, A. T. (2000). Raging hormones, regulated love: Adolescent sexuality and the constitution of the modern individual in the United States of America and the Netherlands. Body and Society, $6,75-105$.

Shows, C., \& Gerstel, N. (2009). Fathering, class and gender: A comparison of physicians and Emergency Medical Technicians. Gender and Society, 23, 161- 187.

Smock, P. (2004). The wax and wane of marriage: Prospects for marriage in the 21 st century. Journal of Marriage and Family, 66, 966-973.

Springer, K. W. (In press). The race and class privilege of motherhood: New York Times presentations of pregnant drug-using women. Sociological Forum.
Stacey, J. (2005). The families of man: Gay male intimacy and kinship in a global metropolis. Signs: Journal of Women in Culture and Society, 30, $1911-1935$.

Stacey, J., \& Biblarz, T. (2001). (How) does the sexual orientation of parents matter? American Sociological Review, 66, 159-183.

Stone, P. (2007). Opting out? Why women really quit careers and head home. Berkeley: University of California Press.

Stratigaki, M. (2004). The cooptation of gender concepts in EU policies: The case of "reconciliation of work and family.' Social Politics, 11, $30-56$.

Sullivan, O. (2004). Changing gender practices within the household: A theoretical perspective. Gender \& Society, 18, 207-222.

Sullivan, O., Coltrane, S., McAnnally, L., \& Altintas, E. (2009). Father-friendly policies and timeuse data in cross-national contexts. Annals of the American Academy of Political and Social Science, $64,234-254$.

Swartz, T. T. (2004). Mothering for the state: Foster parenting and the challenges of governmentcontracted carework. Gender and Society, 18, $567-587$.

Taylor, V., Van Dyke, N., \& Anderson, A. E. (2009). Culture and mobilization: Tactical repertoires, same-sex weddings, and the impact on gay activism. American Sociological Review, 74, $865-890$.

Thistle, S. (2006). From marriage to the market: The transformation of women's lives and work. Berkeley: University of California Press.

Townsend, N. (2003). The package deal: Marriage, work and fatherhood in men's lives. Philadelphia: Temple University Press.

Treas, J., \& deRuijter, E. (2008). Earnings and expenditures on household services in married and cohabiting unions. Journal of Marriage and Family, 70, 796-805.

Tuominen, M. C. (2003). We are not babysitters: Family child care providers redefine work and care. New Brunswick, NJ: Rutgers University Press.

Wade, L. (2009). Defining gendered oppression in U.S. newspapers: The strategic value of "female genital mutilation.' Gender and Society, 23, 293-314.

Waite, L., \& Gallagher, M. (2003). The case for marriage: Why married people are happier, healthier, and better off financially. New York: Broadway Books.

Walby, S. (2009). Globalization and inequalities: Complexity and contested modernities. London: Sage.

Walker, A. (2009). A feminist critique of family studies. In S. Lloyd, A. Few, \& K. Allen (Eds.), 
Handbook of feminist family studies (pp. 18-28). Thousand Oaks, CA: Sage.

West, C., \& Zimmerman, D. (1987). Doing gender. Gender and Society, 1, 125-151.

Whitaker, J. (2003). Seeking compassionate women: The crisis in low-wage healthcare work. (Dissertation). Available from ProQuest Dissertations and Thesis database. (AAT 3101280).

Wilcox, W. B. (2004). Soft patriarchs, new men. Chicago: University of Chicago Press.

Williams, J. C. (2000). Unbending gender: Why work and family conflict and what to do about it. New York: Oxford University Press.
Williams, J. C., \& Boushey, H. (2010). The three faces of work-family conflict. San Francisco: Center for American Progress/WorkLife Law.

Wills, J., \& Risman, B. (2006). The visibility of feminist thought in family studies. Journal of Marriage and Family, 68, 690-700.

Winkler, A. E., McBride, T. D., \& Andrews, C. (2005). Wives who outearn their husbands: A transitory or persistent phenomenon for couples? Demography, 42, 523-535.

Winslow-Bowe, S. (2006). The persistence of wives' income advantage. Journal of Marriage and Family, 68, 824-842. 